\title{
PENGARUH WAKTU PERENDAMAN LAPISAN TIO 2 DALAM DYE EKSTRAK DAUN PACAR KUKU TERHADAP NILAI EFISIENSI DSSC
}

\author{
Israyanti, Iswadi dan Hernawati ${ }^{1}$ \\ 1Jurusan Fisika, Fakultas Sains dan Teknologi, UIN Alauddin Makassar \\ Email: wadi.phys.uin@gmail.com, hernawati@uin-alauddin.ac.id
}

\begin{abstract}
This study is about Dye Sensitized Solar Cell (DSSC) which aims to determine the absorbance value of henna leaf extract (Lawsonia Inermis L) as a sensitizer in DSSC and find out how the effect of immersion time of $\mathrm{TiO} 2$ layer on the efficiency value produced. The method used to make the extract is maceration and to doping $\mathrm{TiO}_{2}$ using the doctor blade method with an area of $1.5 \times 1.5 \mathrm{~cm}$. In this study UV-Vis testing was carried out to determine the absorbance value of dye henna leaf extract, current and voltage testing to determine the current and voltage values obtained from cells and SEM tests to determine the surface structure of $\mathrm{TiO} 2$ layers. The absorbance value of the nail extract leaf extract is based on the results of the UV Vis test which is 0.077 which is located in an area with a wavelength of $663 \mathrm{~nm}$. For the TiO2 coating immersion time obtained the lowest efficiency value of cells with immersion of $\mathrm{TiO} 2$ layer for 1 hour which is $0.0038 \%$, then immersion of TiO2 layer for 12 hours obtained efficiency value $0.0056 \%$ and soaking TiO2 layer for 24 hours obtained efficiency value $0.0083 \%$
\end{abstract}

Keywords: DSSC, dye, absorption, doctor blade, efficiency.

\section{PENDAHULUAN}

Perkembangan dibidang teknologi mengakibatkan kebutuhan manusia terhadap energi semakin meningkat, khususnya energi listrik. Peningkatan terhadap kebutuhan energi ini berbanding terbalik dengan ketersediaan sumber daya yang ada. Dimana energi yang digunakan selama ini berasal dari fosil yang keberadaannya semakin berkurang karena proses pembentukan energi ini memerlukan waktu sekitar seratus tahun lamanya. Salah satu faktor yang mempengaruhi pertumbuhan jumlah penggunaan energi listrik adalah pertumbuhan penduduk. Jumlah penduduk di Indonesia menurut data dari Biro Pusat Statistik (BPS) diperkirakan berjumlah 231.000.000 jiwa pada tahun 2010 dan akan menjadi 293.000.000 pada tahun 2035. Rata-rata pertumbuhan jumlah penduduk berkisar 0,89\%-1,24\% yang tentunya akan berdampak pada penggunaan berbagai sumber daya seperti lahan untuk pemukiman, untuk pertanian, industri, dan masih banyak lagi. Hal ini akan meningkatkan konsumsi energi, termasuk energi listrik (Rohi, 2013). Isu pemerataan akses terhadap listrik juga perlu menjadi perhatian. Sampai 
pada tahun 2014 rasio elektrifikasi (rumah tangga yang teraliri listrik) masih berada di angka 84,35 persen. Masih ada 15,65 persen penduduk Indonesia yang rumahnya belum teraliri listrik (Gultom, 2017).

Oleh karena itu diperlukan alternatif lain, salah satunya dengan menggunakan energi matahari. Sel surya sebagai sumber energi, energi matahari ini sangat memungkinkan pemanfaatannya di Indonesia karena berada di garis khatulistiwa sehingga mendapat sinar matahari yang cukup untuk pengembangan solar cell. Seorang peneliti bernama Michael Gretzel telah berhasil mengembangkan sel surya yang yang dapat mengubah energi matahari menjadi listrik yang dikenal sekarang sebagau Dye Sensitizer Solar Cell (DSSC)(Kristen, 2013). Efek photovoltaic merupakan fenomena munculnya tegangan listrik karena adanya interaksi antara dua elektroda yang dihubungkan dibawah paparan cahaya matahari (Kiruba Daniel, 2013). Cahaya matahari ini dapat dikonversi menjadi energi listrik menggunakan sel surya dengan cara mengkonversi secara langsung radiasi matahari menjadi energi listrik (Damayanti, 2014). Sel surya berdasarkan bahan pembutannya dibagi menjadi dua yaitu dengan menggunakan silikon sebagai bahan dan DSSC (Dye Sensitizer Solar Cell). Dalam proses pembuatannya, DSSC membutuhkan lebih sedikit biaya dibandingkan dengan menggunakan silikon karena menggunakan bahan yang diperoleh dari alam (Supriyanto, 2014). Dengan ketersediaan bahan dengan jumlah yang melimpah di alam maka akan sangat memungkinkan untuk energi matahari dimanfaatkan sebagai sumber energi alternatif sebagai pengganti energi fosil (Kristen, 2013). DSSC umumnya memiliki struktur lapisan seperti sandwich yang terdiri atas elektroda kerja, lapisan TiO2 (Titanium dioxida) dan elektroda lawan yang telah dilapisi katalis. Substrat yang digunakan sebagai tempat eletroda krja maupun elektroda lawan umumnya menggunakan kaca jenis ITO (Indium tin oxida) maupun kaca FTO (Flourine-doped oxida). Pada bagian pasta TiO2 dilapisi pewarna atau dye dan ditambahkan larutan elektrolit diatas lapisan dye agar reaksi antara sel surya dengan sinar matahari lebih cepat (Ardianto, 2015). Dalam DSSC, pewarna alami yang digunakan sebagai sensitizer berfungsi untuk menyerap foton dari matahari kemudian mengubahnya menjadi listrik (Supriyanto, 2014). Salah satu pewarna yang dapat digunakan sebagai sensitizer dalam sel surya ini berasal dari daun pacar kuku (Lawsonia Inermis $L$ ).

Salah satu tanaman yang dikenal memiliki zat warna alami adalah pacar kuku. Tanaman ini tumbuh subur di iklim tropis seperti Indonesia dan tidak terlalu memerlukan perawatan yang khusus dalam pertumbuhannya (W, Soraya, 2013) Warna alami dari daun pacar kuku ialah tampak kuning jingga setelah diekstraksi, berdasarkan skala spektrum cahaya tampak, warna yang diserap adalah warna biru dan biru kehijauan yang memiliki rentang panjang gelombang sekitar 435-490 nm. Pada saat cahaya polikromatis mengenai suatu zat, maka cahaya dengan panjang gelombang tertentu saja yang akan diserap. Jika zat menyerap cahaya tampak (visibel) atau UV maka akan terjadi perpindahan elektron dari keadaan dasar menjadi keadaan tereksitasi (Prestiyana, 2010). Banyak penelitian mengenai DSSC yang telah dilakukan sebelumnya, seperti yang dilakukan oleh (Fitriya, 2016) yang menggunakan daun tembakau sebagai sensitizer dan memvariasikan waktu perendaman lapisan $\mathrm{TiO}_{2}$, kemudian pada penelitian yang dilakukan oleh (Yulia, 2016) dengan menggunakan daun pacar kuku sebagai pewarna alami sebagai 
sensitizer, dimana pewarna yang digunakan dari ekstrak daun pacar kuku yang divariasikan konsentrasinya. Yang membedakan penelitian sebelumnya dengan penelitian ini adalah waktu yang digunakan untuk merendam lapisan $\mathrm{TiO}_{2}$ pada dye dari daun pacar kuku divariasikan agar dapat diketahui bagaimana pengaruh dari waktu perendaman lapisan $\mathrm{TiO} 2$ terhadap nilai efisiensi yang dihasilkan. Berdasarkan uraian di atas, maka diharapkan penelitian dengan judul "Pengaruh Waktu Perendaman Lapisan $\mathrm{TiO}_{2}$ dalam Dye Ekstrak Daun Pacar Kuku Terhadap Nilai Efisiensi DSSC" ini diharapkan dapat memperoleh nilai efisiensi yang lebih besar dari penelitian sebelumnya.

\section{METODE PENELITIAN}

\section{Tahap Pembuatan Ekstrak}

Mencuci daun pacar kuku menggunakan air kemudian menghaluskan menggunakan blender. Serbuk yang dihasilkan kemudian ditimbang 70 gram dan dimasukkkan dalam wadah untuk proses dimaserasi dengan cara direndam menggunakan etanol 96\% selama 24 jam. Hasil rendaman kemudian disaring menggunakan kain penyaring dan corong, selanjutnya melalui proses evaporasi untuk memisahkan ekstrak dengan pelarut. Mengambil $1 \mathrm{ml}$ dye dan dimasukkan ke dalam tabung reaksi dan ditambahkan $9 \mathrm{ml}$ etanol (pengenceran). Pada kuvet 1 dimasukkan etanol sebagai pembacaan blangko dan kuvet 2 dimasukkan larutan dye hasil pengenceran sebagai sampel uji. Kedua kuvet tersebut kemudian dimasukkan ke dalam alat uji untuk melalui proses uji sampel.

\section{Tahap Pembuatan Pasta}

Melarutkan 5 gram bubuk $\mathrm{TiO}_{2}$ kedalam $20 \mathrm{ml}$ aquades dan diaduk sampai proses pelarutan sempurna. Kemudian larutan dipanaskan hingga mendidih. Larutan kemudian disaring sampai terbentuk pasta yang akan dilanjutkan pada proses deposisi.

\section{Pembuatan Lapisan $\mathrm{TiO}_{2}$}

Substrat yang digunakan berupa kaca ITO yang sebelumnya telah dibersihkan menggunakan etanol dan diukur resistensinya menggunakan multimeter. Mendeposisikan pasta $\mathrm{TiO}_{2}$ dengan metode doctor blade dan selanjutnya melalui proses sintering pada suhu $450^{\circ} \mathrm{C}$ selama 30 menit. Sampel kemudian direndam dalam dye selama satu jam. Selama proses perendaman, wadah ditutup menggunakan aluminium foil. Kemudian dilakukan proses yang sama dengan waktu perendaman 12 dan 24 jam.

\section{Pembuatan Elektroda Karbon dan Larutan Elektrolit}

Substrat yang digunakan berupa kaca ITO yang sebelumnya telah dibersihkan menggunakan etanol dan diukur resistensinya menggunakan multimeter. Bagian sisi konduktif kaca dipanaskan sampai terbentuk lapisan karbon. Pada proses pembuatan larutan elektrolit, 3 gram Kalium lodida dimasukkan kedalam spoid. Kemudian ditambahkan $3 \mathrm{ml}$ larutan iodin. Hasil pencampuran kemudian diaduk sampai terbentuk larutan homogen. 


\section{Pembuatan Lapisan Sandwich DSSC}

Menyusun elektroda sampel dengan elektroda karbon secara offside kemudian ditetesi elektrolit diantara elektroda sampel dan elektroda karbon. Kemudian dilanjutkan pada uji arus dan tegangan DSCC untuk mendapatkan parameter listrik meliputi Tegangan, arus, daya dan pencahayaan.

\section{HASIL DAN PEMBAHASAN}

\section{Nilai Absorbansi}

Hubungan antara panjang gelombang $(\mathrm{nm})$ terhadap absorbansi hasil pengamatan Spektroskopi UV-Vis ditunjukkan gambar berikut:

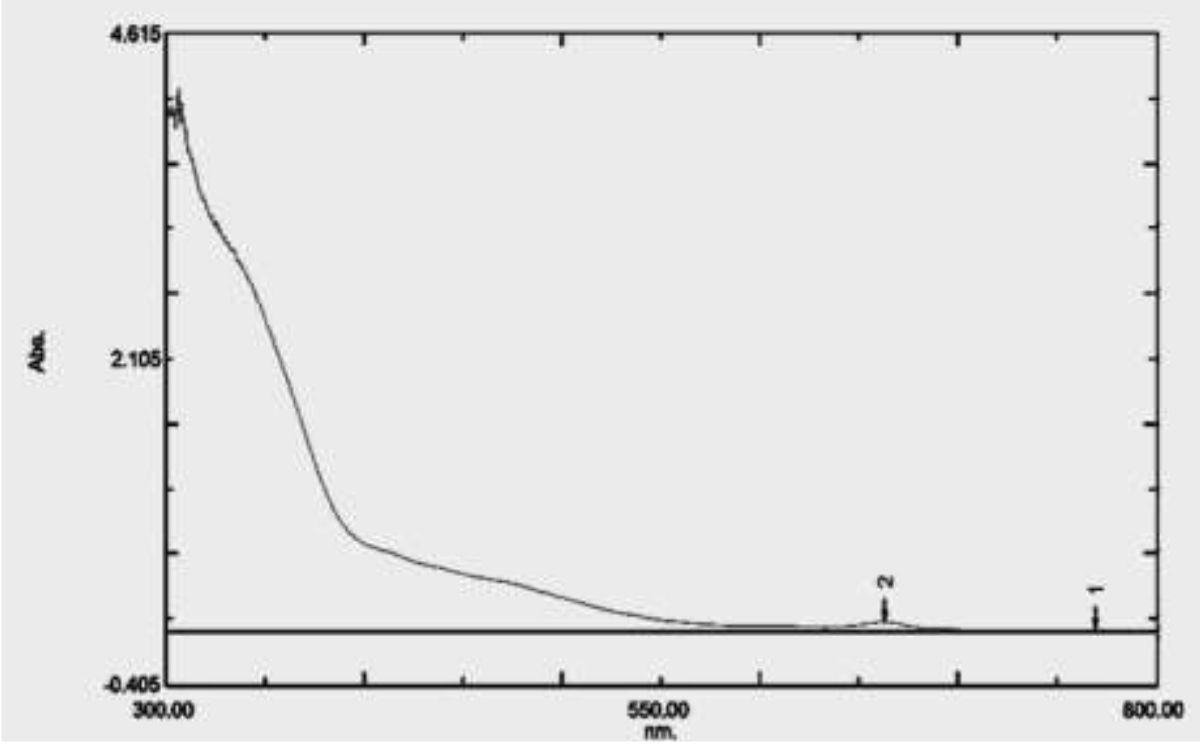

Gambar 1. Hasil pengujian spektrometer UV-Vis larutan dye ekstrak daun pacar kuku

Spektrum absorbansi ekstrak daun pacar kuku pada penelitian ini diukur pada rentang panjang gelombang 300-800 nm. Grafik pada gambar 1 menunjukkan bahwa tingkat absorbansi tertinggi yaitu 0.077 yang terletak pada daerah dengan panjang gelombang $663 \mathrm{~nm}$ sedangkan pada penelitian sebelumnya yang juga menggunakan dye ekstrak daun pacar kuku sebagai sensitizer (Yulia, 2016) nilai absorbansi tertinggi yaitu 0.160 yang terletak pada daerah dengan panjang gelombang $664 \mathrm{~nm}$. Ini menunjukkan bahwa ekstrak daun pacar kuku bekerja pada cahaya tampak dengan warna yang diserap yaitu warna merah $(610-800 \mathrm{~nm})$. Dengan spektrum yang lebar, jenis dye ini bisa menyerap sebagian besar cahaya tampak dari matahari sehingga baik digunakan untuk DSSC (Dye Sensitized Solar Cell). 


\section{Nilai Efisiensi}

Gambar 2 (a) menunjukkan hubungan antara tegangan dan kerapatan arus pada sel dengan lapisan $\mathrm{TiO}_{2}$ direndam selama 1 jam dengan luasan sel $2.25 \mathrm{~cm}^{2}$ sehingga diperoleh hasil pengukuran yaitu Voc $0.104 \mathrm{~V}$, Vmaks $0.087 \mathrm{~V}$, kerapatan arus short sircuit (Jsc) $0.008 \mathrm{~mA} / \mathrm{cm}^{2}$. Daya maksimum diperoleh dari perkalian antara $\mathrm{J}$ dan $\mathrm{V}$ pada masing-masing titik yang terdapat pada grafik diatas sehingga di peroleh nilai daya maksimum yaitu $0.0012 \mathrm{~mW} / \mathrm{cm}^{2}$. Sehingga diperoleh nilai 0.6506 untuk fill factor. Selanjutnya nilai-nilai yang diperoleh ini digunakan untuk menghitung nilai efisiensi sehingga diperoleh nilai $0.003810202 \%$ untuk efisiensi dari sel dengan lama perendaman lapisan $\mathrm{TiO}_{2}$ selama 1 jam.
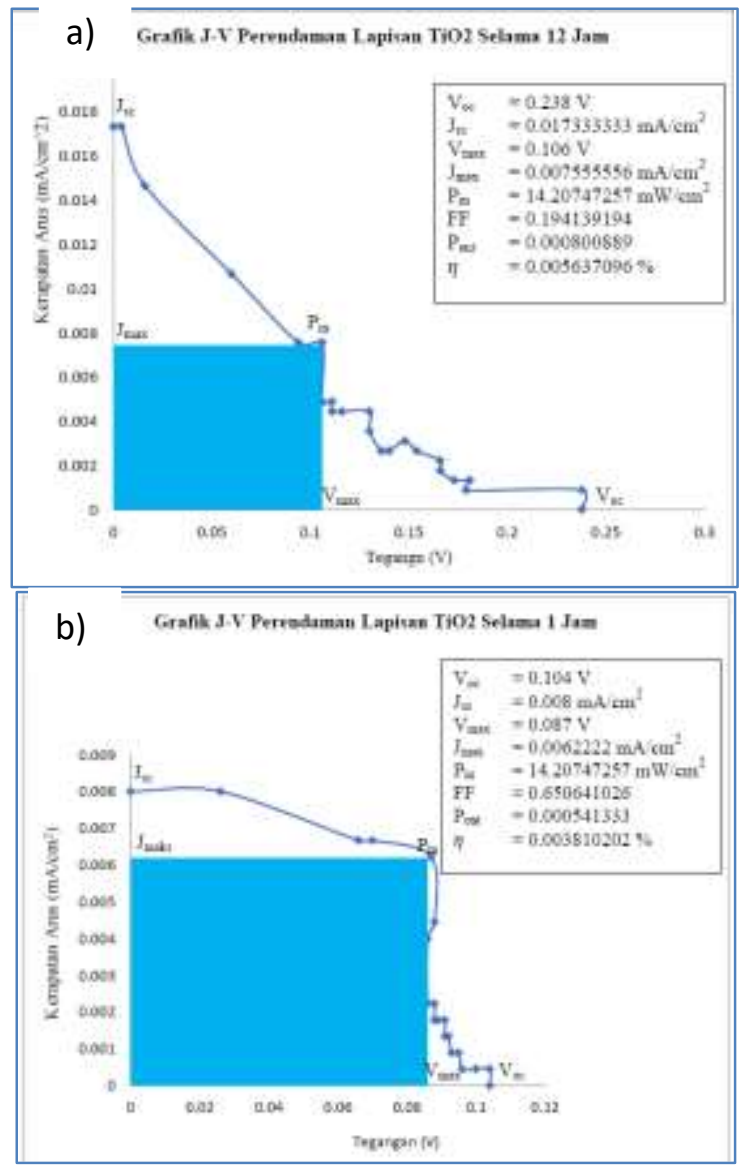


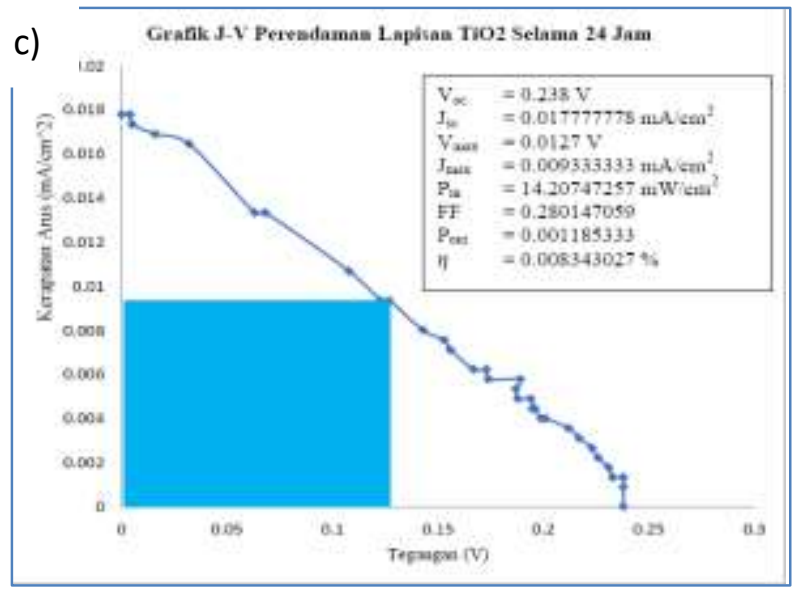

Gambar 2. Grafik J-V perendaman lapisan TiO2 selama (a) 1 jam, (b) 12 jam dan (c) 24 jam

Gambar 2 (b) menunjukkan bahwa kerapatan arus dan tegangan yang diperoleh lebih besar dibandingkan dengan nilai kerapatan arus dan tegangan yang diperoleh berdasarkan grafik 2 (b) Hal ini terlihat dari nilai yang diperoleh, dimana nilai untuk Voc $0.238 \mathrm{~V}$, Vmaks $0.106 \mathrm{~V}$, kerapatan arus short sircuit (Jsc) 0.0073 $\mathrm{mA} / \mathrm{cm}^{2}$, daya maksimum yaitu $0.0018 \mathrm{~mW} / \mathrm{cm}^{2}$. Sehingga diperoleh nilai untuk fill factor yaitu 0.1941. berdasarkan nilai yang diperoleh tadi didapatkanlah nilai efisiensi untuk sel dengan lama perendaman lapisan $\mathrm{TiO}_{2}$ selama 12 jam yaitu = $0.005637096 \%$.

Gambar 2 (c) menunjukkan bahwa Voc 0.238 V, Vmaks 0.127 V, kerapatan arus short sircuit (Jsc) $0.0178 \mathrm{~mA} / \mathrm{cm}^{2}$, daya maksimum yaitu $0.0027 \mathrm{~mW} / \mathrm{cm}^{2}$. Selanjutnya untuk fill factor diperoleh nilai 0.2801 . Sehingga diperoleh nilai efisiensi $0.0083 \%$ dari sel dengan lama perendaman lapisan $\mathrm{TiO}_{2}$ selama 24 jam.

Berikut hasil pengujian arus dan tegangan DSSC dengan waktu perendaman lapisan $\mathrm{TiO}_{2}$ yang berbeda-beda yakni 1 jam, 12 jam dan 24 jam perbedaan nilai efisiensinya dapat dilihat pada tabel berikut:

Tabel 1. Hasil perhitungan efisiensi DSSC

\begin{tabular}{|c|c|c|c|c|}
\hline $\begin{array}{c}\text { Lama perendaman } \\
\text { lapisan TiO2 (Jam) }\end{array}$ & Voc $(\mathrm{V})$ & $\mathrm{Jsc}\left(\mathrm{mA} / \mathrm{cm}^{2}\right)$ & $\mathrm{FF}$ & $\mathrm{H}(\%)$ \\
\hline 1 & 0,104 & 0,046222 & 0,650641 & 0,00381 \\
\hline 12 & 0,238 & 0,105778 & 0,194139 & 0,005637 \\
\hline 24 & 0,238 & 0,105778 & 0,280147 & 0,008343 \\
\hline
\end{tabular}

Berdasarkan tabel diatas dapat diketahui bahwa nilai efisiensi maksimal diperoleh dari lapisan $\mathrm{TiO}_{2}$ dengan lama perendaman 24 jam yaitu $0.008343 \%$. Sedangkan nilai efisiensi yang diperoleh pada penelitian sebelumnya yang juga menggunakan dye ekstrak daun pacar kuku sebagai sensitizer (Yulia, 2016) diperoleh efisiensi sebesar 0.0033264\% dan (Fuadhi, 2009) diperoleh nilai efisiensi 
0.00224\%. Nilai efisiensi yang diperoleh pada penenlitian ini lebih tinggi dibandingkan dengan penelitian yang dilakukan oleh (Yulia, 2016) dan (Fuadhi, 2009). Hal ini dapat disebabkan oleh perbedaan suhu dan lama waktu sintering yang digunakan.

\section{Morfologi Permukaan Lapisan TiO2 dengan Uji SEM}

Tahap akhir dari penelitian ini adalah melakukan uji SEM (Scanning Electron Microscopy) untuk mengetahui morfologi dari masing-masing lapisan TiO2 yang telah direndam dalam dye ektrak daun pacar kuku dengan variasi waktu perendaman 1 jam, 12 jam dan 24 jam. Pengujian SEM dilakukan dengan menggunakan SEM vega3 tescan. Berikut merupakan gambar hasil pengujian SEM dari lapisan TiO2 yang telah direndam dalam dye selama 1 jam, 12 jam dan 24 jam:

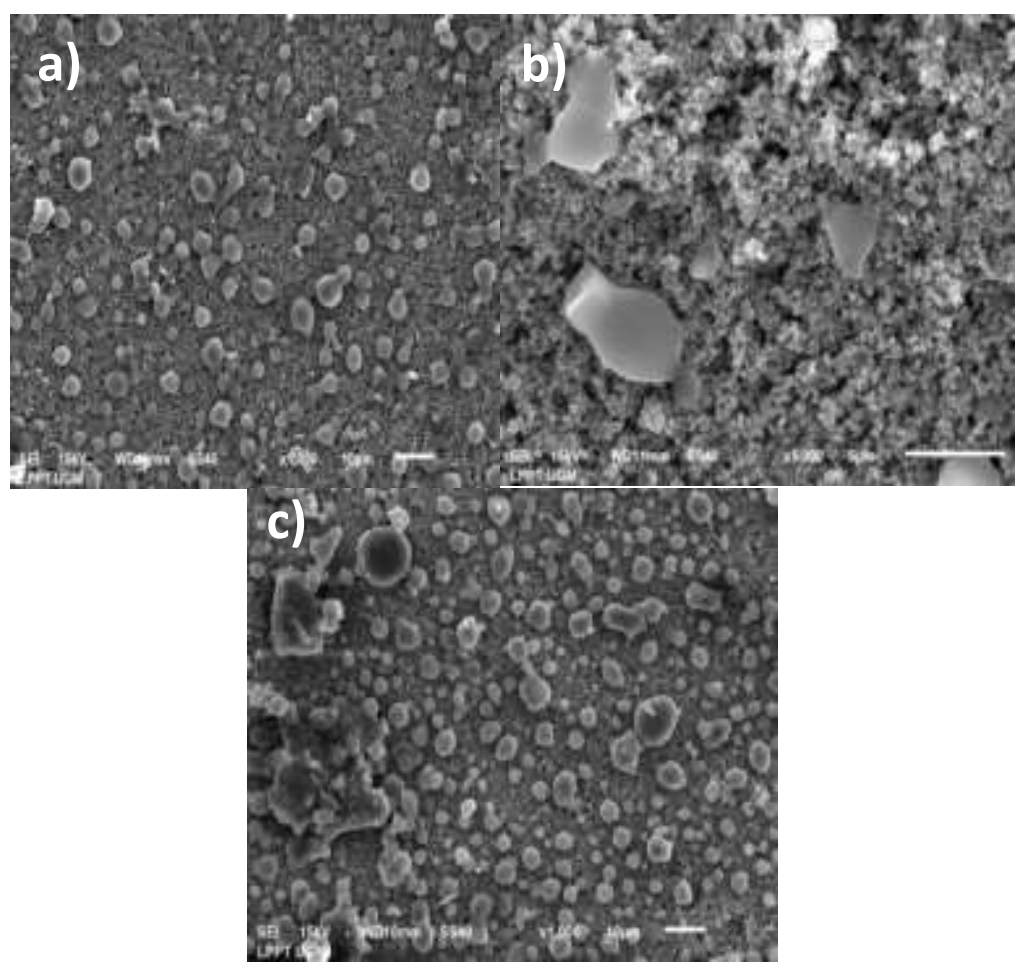




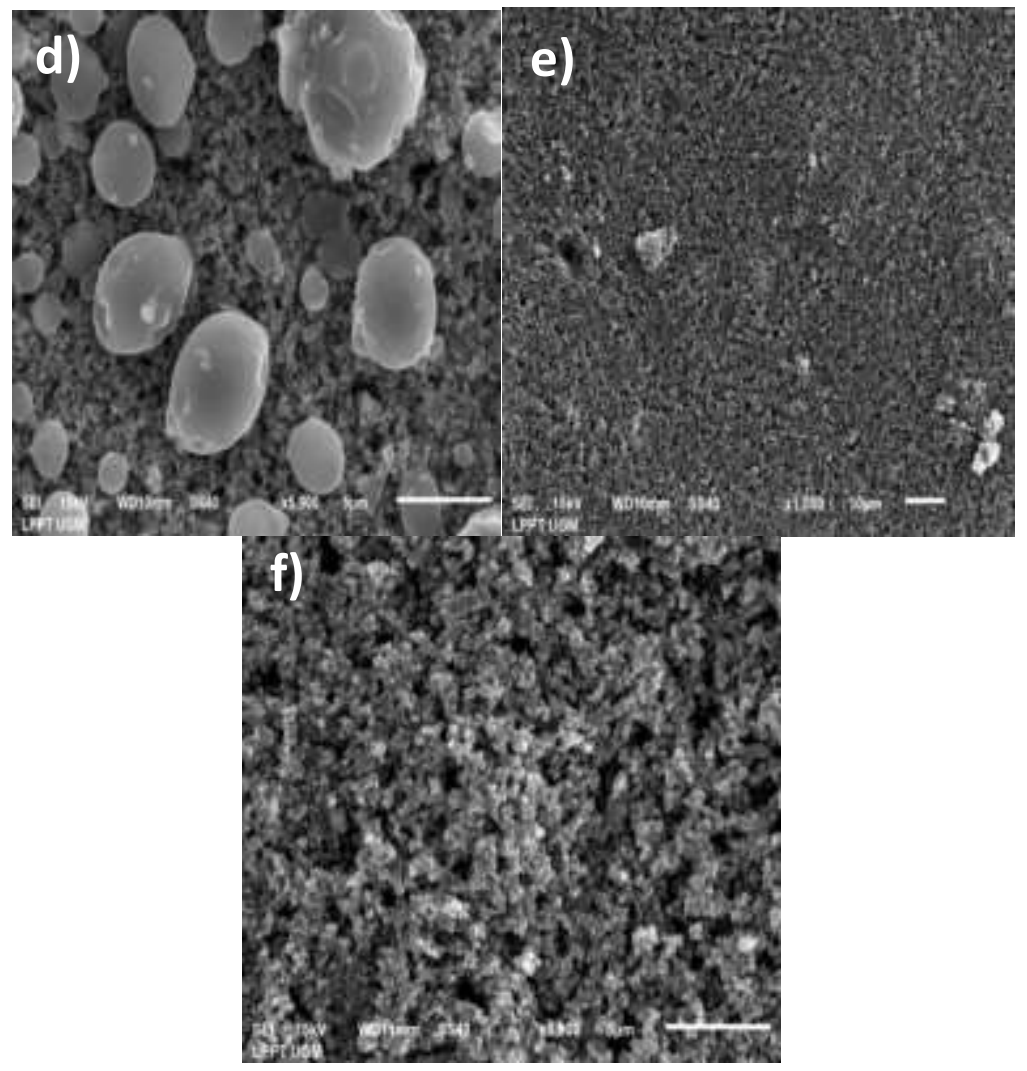

Gambar 3. Morfologi permukaan lapisan $\mathrm{TiO}_{2}$ dengan:

(a) waktu perendaman selama 1 jam perbesaran 1.000x; (b) waktu perendaman selama 1 jam perbesaran 5.000x; (c) waktu perendaman selama 12 jam perbesaran 1.000x; (d) waktu perendaman selama 12 jam perbesaran 5.000x; (e) waktu perendaman selama 24 jam perbesaran 1.000x; (f) waktu perendaman selama 24 jam perbesaran $5.000 x$

Hasil morfologi dengan warna terang menunjukkan $\mathrm{TiO}_{2}$ sedangkan warna putih menunjukkan dye pada permukaan partikel-partikel $\mathrm{TiO}_{2}$. Hasil permukaan lapisan $\mathrm{TiO}_{2}$ dengan waktu perendaman selama 1 jam pada gambar 3 (a) terlihat struktur yang kurang merata sehingga menghasilkan sedikit rongga/pori, kemudian pada hasil permukaan lapisan $\mathrm{TiO}_{2}$ dengan waktu perendaman selama 12 jam pada strukturnya terdapat rongga sedikit lebih banyak dibandingkan dengan perendaman selama 1 jam seperti yang terlihat pada gambar 3 (c) dan hasil permukaan lapisan TiO2 dengan waktu perendaman selama 24 jam struktur yang dihasilkan agak merata sehingga rongga yang dihasilkan cukup banyak seperti yang tampak pada gambar 3 (e). Untuk menghasilkan arus dan tegangan yang efisien pada DSSC dibutuhkan kaca konduktif dengan nilai resistansi rendah. Selain itu, dibutuhkan pula struktur lapisan $\mathrm{TiO}_{2}$ yang merata agar menghasillkan banyak pori yang dapat menyerap banyak dye sehingga banyak pula elektron yang dapat tereksitasi ketika permukaan sel terpapar cahaya matahari. 


\section{KESIMPULAN}

Adapun kesimpulan dari hasil penelitian ini adalah:

1. Nilai absorbansi pada ekstrak daun pacar kuku sebagai bahan sensitizer pada DSSC diperoleh nilai yaitu 0.077 yang terletak pada daerah dengan panjang gelombang $663 \mathrm{~nm}$.

2. Waktu perendaman lapisan $\mathrm{TiO} 2$ berpengaruh terhadap nilai efisiensi, dimana nilai efisiensi terendah diperoleh dari sel dengan perendaman lapisan TiO2 selama 1 jam yaitu $0.0038 \%$, kemudian perendaman lapisan TiO2 selama 12 jam diperoleh nilai efisiensi $0.0056 \%$ dan perendaman lapisan $\mathrm{TiO} 2$ selama 24 jam diperoleh nilai efisiensi $0.0083 \%$.

\section{DAFTAR PUSTAKA}

Ardianto, Rino et al., 2015. Jurnal Keteknikan Pertanian Tropis dan Biosistem. Uji Kinerja Dye Sensitized Solar Cell (DSSC) menggunakan Lapisan Capacitive Touchscreen Sebagai Substrat dan Ekstrak Klorofil Nannochloropsis Sp. sebagai Dye Sensitizer dengan Variasi Ketebalan Pasta $\mathrm{TiO}_{2}$.

Anggraeni, Nuha Desi., 2008. "Analisa SEM (Scanning Electron Microscopy ) dalam Pemantauan Proses Oksidasi Magnetite Menjadi Hematite." Seminar Nasional - VII Rekayasa dan Aplikasi Teknik Mesin di Industri (October 2014): 50-56.

Alfanz, Rocky et al., 2015. "Rancang Bangun Penyedia Energi Listrik Tenaga Hibrida (PLTS- PLTB-PLN) Untuk Membantu Pasokan Listrik Rumah Tinggal." Setrum 4(2): 34-42.

Dwi Fahyuan, Helga, Faizar Farid, and dan Sarina Pakpahan., 2015. 1 JoP Disain Prototipe Sel Surya Dssc (Dye Sensitized Solar Cell) Lapisan Grafit/Tio 2 Berbasis Dye Alami Abstract [Title: Solar Cell Prototype Design Of Dssc (Dye Sensitized Solar Cell) Graphite Coating / Tio2 Based On Natural Dye] A Research on Solar Cells Prototype Design DSSC Layer Graphite / TiO2Based Natural.

Fitria, Anisa et al., 2016. 3 Jom FTEKNIK Pembuatan Prototip Dye Sensitized Solar Cell (DSSC) Menggunakan Dye Ekstrak Buah Senduduk (Melastoma Malabathricum L) Dengan Variasi Fraksi Pelarut Dan Lama Perendaman Coating $\mathrm{TiO}_{2}$.

Gultom, Togar Timoteus, and Masyarakat Indonesia., 2017. "Pemenuhan Sumber Tenaga Listrik Di Indonesia." 3(1).

Kristen, Universitas, and Satya Wacana. 2013. "Pembuatan Prototipe." 4(1): 345-50.

Noly, Ariza, and A Metodologi Penelitian., 2012. "Sintesis Dan Karakterisasi Sifat Magnetik Serbuk Barium M-Heksaferrit Dengan Doping lon Zn Pada Variasi Temperatur Rendah." 1(1): 52-54. 
Rohi, Daniel, and Jandy E.Luik., "Kesadaran Masyarakat Surabaya Untuk Memiliki Gaya Hidup Ramah Lingkungan, Green Living melalui Menghemat Penggunaan Energi Listrik." : 1-17.

Sujatno, Agus, Rohmad Salam, and Arbi Dimyati Pusat Sains dan Teknologi Bahan Maju., 2015. "Studi Scanning Electron Microscopy (Sem) untuk Karakterisasi Proses Oxidasi Paduan Zirkonium.” Jurnal Forum Nuklir (JFN) 9(2): 44-50.

Teknik, Fakultas, Universitas Negeri Surabaya., 2015. "Pengaruh Konsentrasi Mordan Kapur dengan Zat Warna Daun Pacar Kuku ( Lawsonia Inermis ) Kering terhadap Pewarnaan Kain Knit Cotton Shella Setiana Juhrah Singke Abstrak." 04.

Triyati, Oleh Etty., 1985. "Spektrofotometer Ultra-Violet dan Sinar Tampak serta Aplikasinya dalam Oseanologi." 1(1): 39-47.

W, Soraya Ratna., 2013. "Pembuatan Sediaan Pewarna Rambut dalam Bentuk Gel dari Infus Pacar Kuku." : 1-12. 